\title{
Nanofibers Offer Alternative Ways to the Treatment of Skin Infections
}

\author{
T. D. J. Heunis and L. M. T. Dicks \\ Department of Microbiology, University of Stellenbosch, Matieland, Stellenbosch 7602, South Africa \\ Correspondence should be addressed to L. M. T. Dicks, lmtd@sun.ac.za
}

Received 18 March 2010; Accepted 8 June 2010

Academic Editor: Effie Tsakalidou

Copyright ( $) 2010$ T. D. J. Heunis and L. M. T. Dicks. This is an open access article distributed under the Creative Commons Attribution License, which permits unrestricted use, distribution, and reproduction in any medium, provided the original work is properly cited.

Injury to the skin causes a breach in the protective layer surrounding the body. Many pathogens are resistant to antibiotics, rendering conventional treatment less effective. This led to the use of alternative antimicrobial compounds, such as silver ions, in skin treatment. In this review nanofibers, and the incorporation of natural antimicrobial compounds in these scaffolds, are discussed as an alternative way to control skin infections. Electrospinning as a technique to prepare nanofibers is discussed. The possibility of using these structures as drug delivery systems is investigated.

\section{Introduction}

Severe skin damage and loss of the protective layer exposes underlying tissue to secondary infections $[1,2]$. In the United States, treatment of fire and burn wound infections amount to more than 7.5 billion US dollars per annum [3]. From one million patients, an estimated 10000 die from secondary microbial infections [2, 4-9]. If wounds are not treated effectively, pathogens form biofilms, rendering them resistant to antibiotics [10-13]. In severe cases, biofilms need to be surgically removed to prevent further infection [14].

Staphylococcus aureus, including methicillin resistant strains (MRSA), are the most prevalent in skin infections. Pseudomonas aeruginosa, Escherichia coli, Acinetobacter spp., and coagulase-negative staphylococci have also been isolated from skin lesions [15-19]. More than $95 \%$ of S. aureus strains are resistant to penicillin and $60-70 \%$ are resistant to methicillin [20-22]. Methicillin resistance is attributed to the mec $A$ gene encoding penicillin binding proteins $[20,23]$. These proteins occur in the cell wall and play a role in the synthesis of peptidoglycan and are usually inactivated by beta-lactam antibiotics. However, in MRSA the mec A gene encodes a low-antibiotic affinity penicillin binding protein, known as $\mathrm{PBP} 2 \mathrm{a}$, conferring methicillin resistance to the cells [20]. Some MRSA strains are also resistant to tetracyclines, sulphonamides, trimethoprim, macrolides, aminoglycosides, mupirocin, mafenide acetate, silver sulphadiazine, bacitracin, ciprofloxacin, and vancomycin [24-29]. Vancomycin-resistant enterococci and $P$. aeruginosa strains resistant to several antibiotics have also been reported [30].

This review focuses on the treatment of skin infections and open wounds and the biomedical application of electrospun nanofibers, with specific emphasis on antimicrobial delivery systems. Antimicrobials other than antibiotics are discussed.

\section{Current Treatment of Skin Infections and Drawbacks}

Most data on skin infections are from publications on burn wounds. Several treatments have been proposed. Silver sulfadiazine, a combination of silver nitrate and sodium sulfadiazine, has been used to treat invasive burn wound sepsis $[6,14,32,33]$. With prolonged use, silver ions may be toxic, as it binds to DNA and prevents replication [34, 35]. Furthermore, some pathogens have developed resistance to silver [36-38].

Mafenide acetate and chlorexidine digluconate creams have been used to treat burn wound infections $[14,39]$. 
The disadvantage of these topical creams is that they have to be applied twice daily. If incorporated in wound dressings, the bandages have to be changed daily, which may expose the wound to further infection [40]. As in the case of many other antimicrobials, pathogens with resistance to mafenide acetate have been reported, especially when used over an extended period [27]. Mupirocin has also been used in the treatment of burn wound infections [41].

Nanotechnology offers the latest alternatives to wound dressings, of which Acticoat A.B, Silverlon, and Silvasorb with nanoparticles are good examples. Supporters of this technology claim that the nanocrystalline silver particles are released in a controlled manner, inhibiting the growth of a broad spectrum of pathogens [43-45]. Entrance of the nanoparticles into cells and their mode of action is summarized in Figure 1. Endosomes, filled with silver nanoparticles, lysosomes, and silver nanoparticles in the nucleus of treated cells, have been observed. Cells may also take up silver nanoparticles via endocytosis.

Some concerns exist regarding the medical use of silver particles, as they form reactive oxygen species (ROS), reduce ATP, and damage mitochondria and DNA [31, 46]. Furthermore, silver nanoparticles caused an inflammatory response in a murine model system [47]. Silver nanoparticles are, however, less toxic compared to gold nanoparticles, as observed in experiments with J774 A1 murine macrophages [48].

\section{Production of Nanofibers}

Nanofibers are produced from polymers treated in a specific manner to form threads of a few micrometers to nanometers in diameter. The large surface to volume ratio, and manipulation of surface properties, renders nanofibers the ideal matrix to develop super fine structures [49-51]. The possibility to immobilize antibiotics, enzymes, antimicrobial peptides, and growth hormones to nanofibers, or encapsulation into fiber matrixes, opens a new field in biomedical engineering [5260].

Several methods are used to produce ultra fine fibers, for example, self assembly of polymers, template synthesis, phase separation, and electrospinning [49, 62-66]. Electrospinning, schematically presented in Figure 2, is the most cost effective and easiest way to produce large volumes of nanofibers. One electrode is placed in a polymer solution and the other electrode is linked to a collector, which is usually a stationary or rotating metal screen, plate, or wheel. The electrically charged polymer forms a Taylor cone at the tip of the needle and is ejected at a specific charge. As the polymer solution accelerates, the solvent evaporates and nanofibers are formed. Fibers are aligned by using a rotating collector, an auxiliary electrical field, or a rotating collector with a sharp edge and a rapidly oscillating frame [67-71]. Coaxial electrospinning (Figure 3(a)) is used to produce nanofibers with a core-shell structure (Figure 4(a)), which is ideal for encapsulating hydrophilic molecules. Coaxial spun fibers have a high loading efficiency $[56,72]$. Emulsion electrospinning is also used to produce core-shellstructured nanofibers (Figures 3(b) and 4(b)). An emulsion

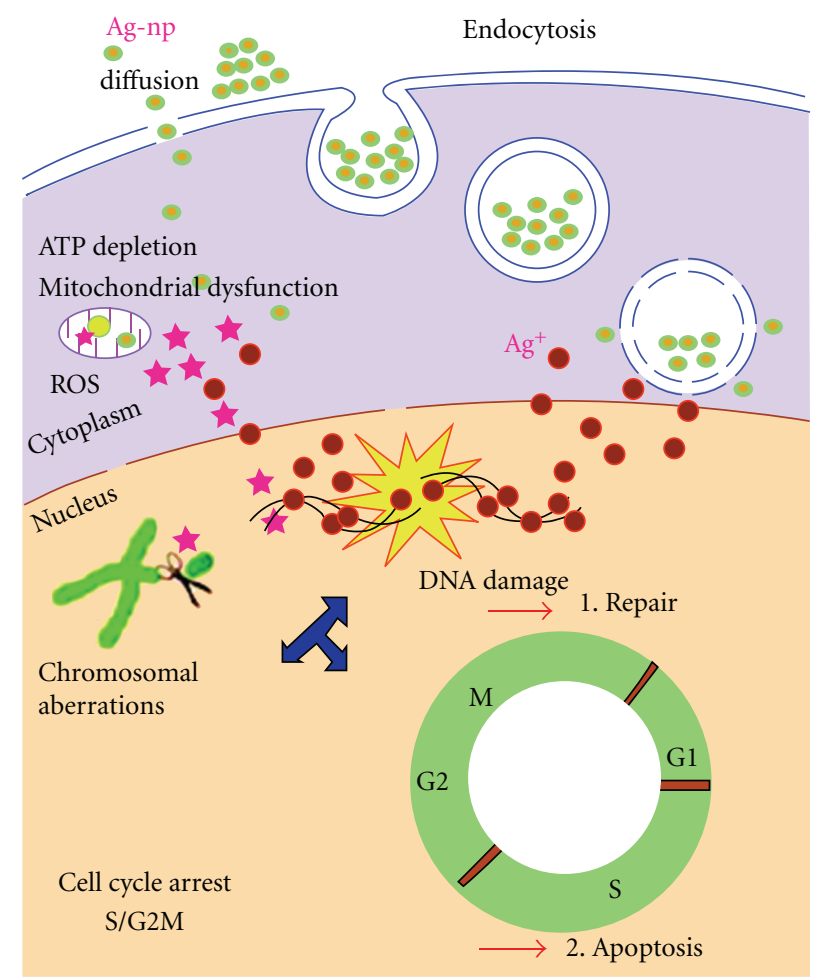

FIGURE 1: Illustration of the uptake of silver nanoparticles, via endocytosis, and the mechanisms by which they cause toxicity to cells [31].

is prepared by emulsifying an aqueous phase, which contains a hydrophilic polymer or molecule to be encapsulated, into an organic phase containing a polymer that forms the shell $[42,61]$. The emulsion is then electrospun into core-shellstructured nanofibers (Figure 4(b)).

\section{Parameters That Influence Nanofiber Formation and the Electrospinning Process}

The quality and characteristics of the final product are determined by the temperature, viscosity, elasticity, conductivity, and surface tension of the solution, strength of the electric field, distance between the needle tip and collector, and humidity $[49,73,74]$. Larger fibers (bigger diameter) are obtained by increasing the concentration of the polymer in solution. Polyvinylpyrrolidone (PVP) at $4 \%(\mathrm{w} / \mathrm{w})$ in a $50: 50(\mathrm{w} / \mathrm{w})$ dimethylformamide : ethanol solution is used to produces fibers of $20 \mathrm{~nm}$ in diameter [75]. However, PVP at $8 \%(w / w)$ in the same solution produces fibers of $50 \mathrm{~nm}$ in diameter, and PVP at $10 \%(\mathrm{w} / \mathrm{w})$ produce fibers of $300 \mathrm{~nm}$ in diameter. Electrospinning different concentrations of poly L-lactic acid (PLLA) in a chloroform solution produce nanofibers with different morphologies (Figure 5). PLLA of $1 \%(\mathrm{w} / \mathrm{w})$ produces a "bead on a string" structure whereas $3 \%$ (w/w) PLLA forms nanofibers with a smooth structure [61]. 


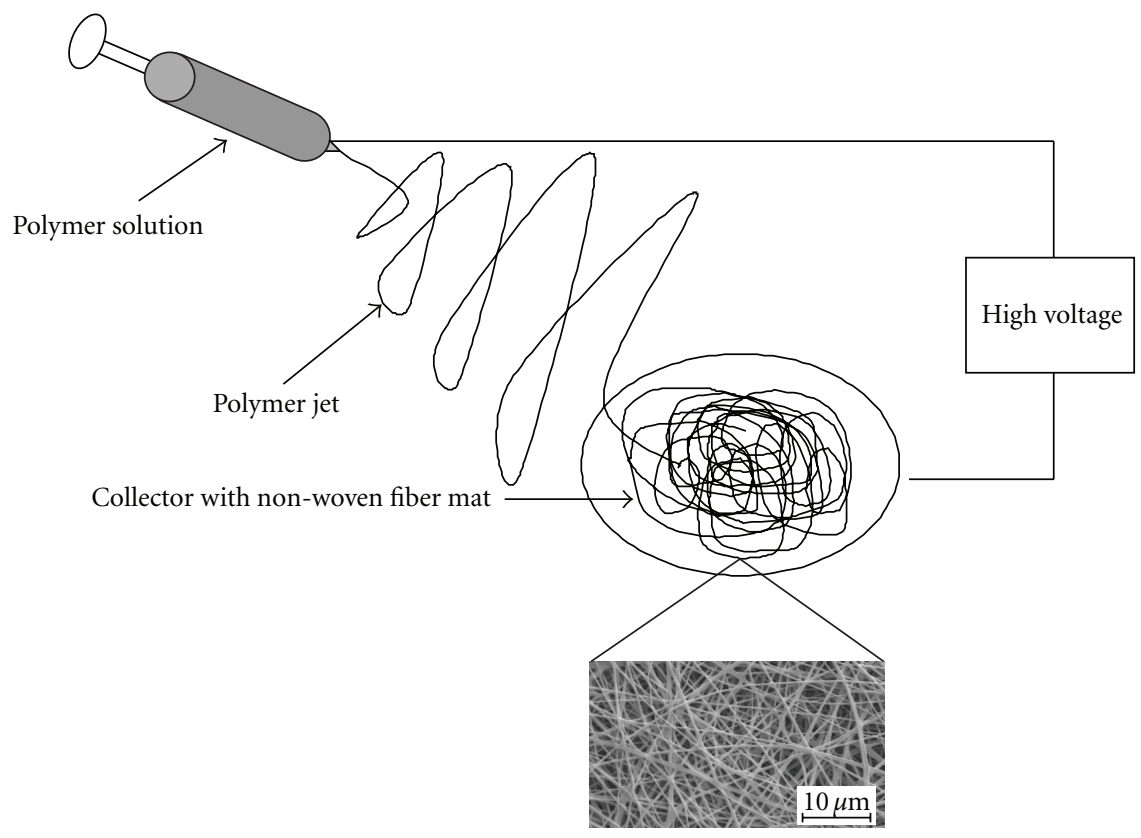

FIGURE 2: Schematic representation of the electospinning process.

Solvents influence the surface tension and viscosity of the solution and affect the morphology of fibers [75, 76]. PVP $(4 \%, w / w)$ dissolved in dichloromethane (MC) forms fibers with spindle-like beads and hollow or solid structures whereas the same concentration PVP in N,Ndimethylformamide (DMF) forms sphere-like beads with solid structures. PVP dissolved in ethanol yields smooth fibers with a diameter ranging from 100 to $625 \mathrm{~nm}$ [75]. The PVP/DMF and PVP/MC solutions have a high surface tension (47.1 and 38.7 centipoise, resp.) and low viscosity (9.8 and 13.0 centipoise, resp.). A PVP/ethanol solution, on the other hand, has a low surface tension (29.3 centipoise) and high viscosity (17.3 centipoise). Different solvents evaporate at different speeds and affect the structure of the fibers [76]. Changes in current may also affect the morphology of fibers, as observed with polyethylene oxide (PEO). An increase from $5.5 \mathrm{kV}$ to $9.0 \mathrm{kV}$ changed the morphology of the PEO fibers from smooth to a "bead on a string" structure [74]. The importance of processing variables that influence fiber morphology during electrospinning is reviewed by Deitzel et al. [74].

\section{Electrospun Nanofibers in Biomedical Engineering as Drug Delivery Vehicles}

Natural and synthetic polymers have been spun into nanofibers for potential use in biomedical engineering [53, 54, 61, 76-79]. Chitin, a structural polysaccharide from arthropods, yielded fibers ranging from 40 to $600 \mathrm{~nm}$ in diameter [79]. A combination of water-soluble carboxyethyl chitosan and poly-vinyl alcohol (PVA) was electrospun to produce a wound dressing. The nanofibers revealed no toxicity when tested with a mouse fibroblast L929 cell line, and promoted cell attachment and proliferation [78].
Chitosan acetate bandages proved effective as an antimicrobial dressing when tested on BALB/c mice with burn wounds that have been infected with $P$. aeruginosa and Proteus mirabilis [80].

Hydrophilic and hydrophobic polymer blends have also been spun into biodegradable nanofibers. The hydrophobic polymer provides the structure or "backbone" and degrades over a long period whereas the more hydrophilic polymer degrades or dissolves faster. The choice of polymer or polymer blends play an important role in devices aimed at controlled release. Examples of using hydrophilic and/or hydrophobic polymers for the controlled release of molecules, for example, antibiotics, plasmids, growth factors, proteins, silver particles, bacteria and viruses will be discussed in more detail [54, 61, 82, 83, 89, 93].

5.1. Antibiotics. Rifampin, encapsulated in PLLA during electrospinning, and incubated in a $0.05 \mathrm{M}$ Tris- $\mathrm{HCl}$ buffer, was only released when proteinase $\mathrm{K}$ was added to the solution. This suggests that the release of rifampin was initiated by the degradation of PLLA and not by normal diffusion [81]. In another experiment, doxorubicin hydrochloride and paclitaxil were encapsulated into PLLA nanofibers [81]. Doxorubicin hydrochloride was detected on the surface of the nanofibers but paclitaxil remained encapsulated. Rifampin and paclitaxil were more soluble in the chloroform/acetone solvent compared to doxorubicin hydrochloride. The solubility of the molecule to be encapsulated in the polymer solvent plays an important role in its distribution throughout the nanofibers. Tetracycline hydrochloride $(5 \%$, $\mathrm{w} / \mathrm{w}$ ) encapsulated in poly-ethylene-co-vinyl acetate (PEVA), or in a blend of PEVA and PLLA, has a relatively slow and consistent release rate [60]. The PEVA and PEVA/PLLA blend containing $5 \%(\mathrm{w} / \mathrm{w})$ tetracycline hydrochloride had 


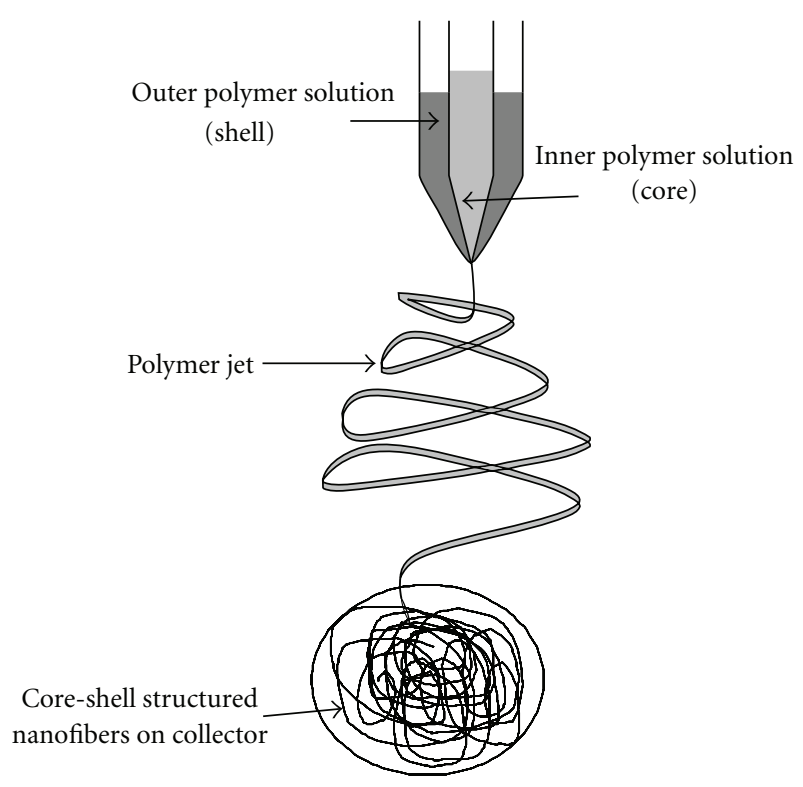

(a)

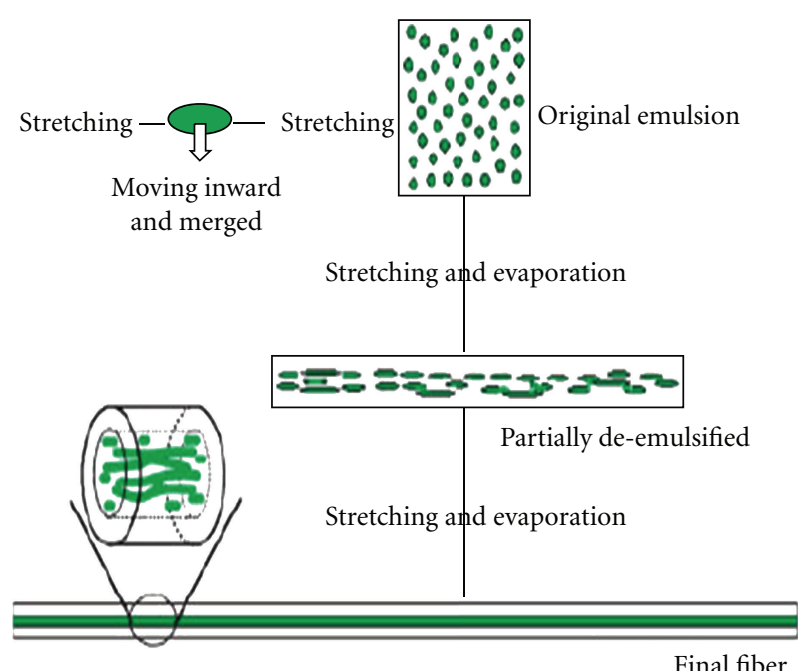

(b)

FIgURE 3: (a) Schematic representation of the needle setup used in coaxial electrospinning and (b) representation of the formation of core-shell structured nanofibers by emulsion electrospininng [42].

a similar release rate to Actisite, a commercial drug delivery system, following the initial high burst release. The antibiotic Mefoxin (cefoxitin sodium) was encapsulated in poly-lactate-co-glycolide (PLGA) fibers and in fibers consisting of a poly-lactate-co-glycolide/polyethylene glycol-blockpoly(L-lactide) copolymer (PLGA/PEG-b-PLLA). Mefoxin released from the fibers inhibited the growth of $S$. aureus in culture and on an agar surface. PEG-b-PLLA prolonged the drug release for up to one week [82].

5.2. Plasmid DNA. The feasibility of encapsulating plasmid DNA in electrospun nanofibers and to use these nanofibers as gene delivery vehicles has also been shown [83]. PLGA and a PLA-PEG block copolymer was electrospun with a 7164 bp plasmid ( $\mathrm{pCMV} \beta$ ), encoding $\beta$-galactosidase. The majority of plasmid DNA was released over 20 days. The bioactivity of $\mathrm{pCMV} \beta$ was evaluated by conducting transfection experiments with preosteoblastic MC3T3 cells. The $\beta$-galactosidase gene was successfully expressed by preosteoblastic MC3T3 cells that have taken up the plasmid.

5.3. Growth Factors. Human $\beta$-nerve growth factor (NGF) was encapsulated into fibers consisting of a copolymer of poly $\mathcal{E}$-caprolactone and ethyl ethylene phosphate (PCLEEP) through electrospinning [54]. The bioactivity of NGF was evaluated by incubating rat pheochromocytoma (PC 12) cells in the supernatant of nanofibers containing encapsulated NGF and searching for differentiation into neurons. Bioactivity was recorded for up to three months. Human glialcell-derived neurotrophic factor (GDNF), encapsulated into PCLEEP nanofibers, was released in active form for up to two months [84]. A $15 \mathrm{~mm}$ nerve lesion was made in the left sciatic nerve of 3.5 month-old Sprague-Dawley rats. The rats then received longitudinally aligned fibers impregnated with GDNF. Longitudinally or circumferentially aligned fibers with no GDNF encapsulated within served as controls. In rats that received encapsulated GDNF, a bridge formed across the lesion and the nerve was regenerated after three months. However, the nerve system in only half the number of rats that received control fibers was regenerated. The stimulation of bone regeneration in nude mice that have been treated with bone morphogenetic protein-2 (BMP-2) encapsulated in PLGA-hydroxyapatite (HAp) nanofibers was also shown in [85]. Bioactive BMP-2 was released from the nanofibers over four weeks.

5.4. Proteins. Lysozyme was encapsulated in biodegradable poly- $\varepsilon$-caprolactone (PCL) and PEO fibers [53]. The highest release of lysozyme (87\% over 12 days) was recorded in a PEO/PCL nanofiber with a 90/10 ratio. The released lysozyme maintained $90 \%$ of its catalytic activity. Cytochrome $\mathrm{C}$ has been encapsulated in nanofibers by emulsion electrospinning [61]. This was done by emulsifying an aqueous solution of cytochrome $\mathrm{C}$ in a chloroform solution containing PLLA. High encapsulation efficiencies ( $85 \%$ to $95 \%$ ) were recorded after spinning. However, low levels of cytochrome $\mathrm{C}$ were released. Controlled release was obtained when PLLA was blended with poly(L-lysine) (PLL) and poly(ethylene imine) (PEI), hydrophilic polymers. A blend containing 50\% PLL released most of the protein $(75 \%)$ with a high initial burst release.

5.5. Bacteria and Viruses. Escherichia coli, Staphylococcus albus, and bacteriophages T7, T4, and $\lambda$ were encapsulated in PVA nanofibers with water as solvent [88]. The encapsulated cells and bacteriophages survived the electrospinning process and remained viable for three months at -20 and $-55^{\circ} \mathrm{C}$. M13 viruses were encapsulated into PVP nanofibers [91]. The fibers were dissolved in a tris-buffered saline solution ( $\mathrm{pH} 7.5)$. The released viruses were still able to infect bacterial cells. Micrococcus luteus and E. coli were encapsulated into PEO nanofibers with water as solvent [89]. Up to $74 \%$ of the M. luteus cells, but only $0.1 \%$ 


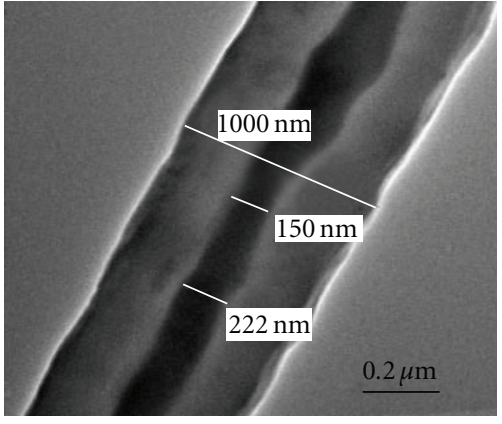

(a)

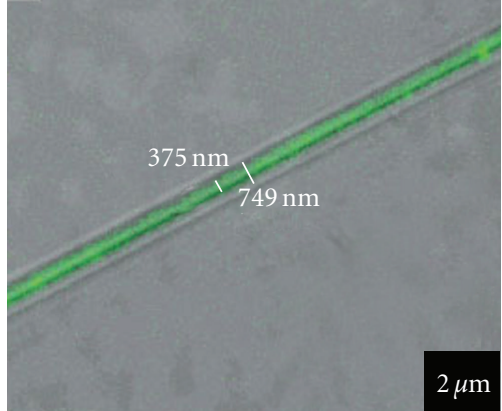

(b)

FIGURE 4: Core-shell structured nanofibers produced from (a) coaxial electrospun PEO and poly-dodecyl thiophene (PDT), with PDT forming the core structure [23] and (b) emulsion electrospun poly(ethylene glycol)-poly(L-lactic acid) diblock copolymer (PEG750-PLA) and PEO (the core is visible by labeling PEO with fluorescein isothiocyanate, FITC) [24].

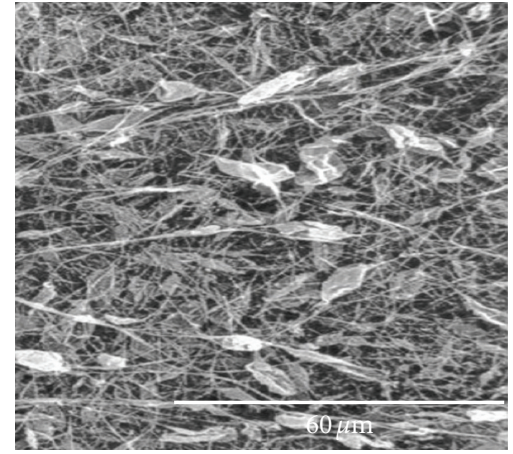

(a)

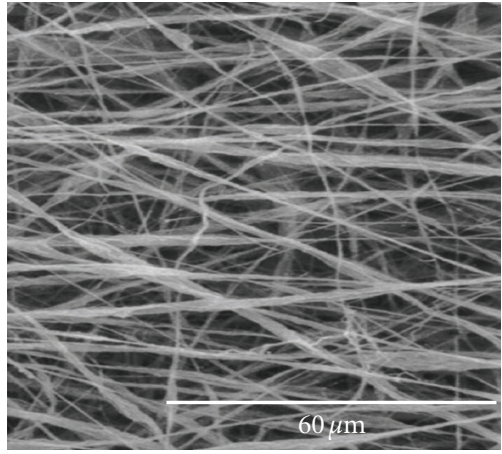

(b)

FIgURE 5: Fibers produced from electrospinning with (a) 1\% (w/w) PLLA (the "bead on a string" morphology is clearly visible) and (b) 3\% (w/w) PLLA, showing a smooth structure [61].

of the E. coli cells, survived the electrospinning process. We recently reported on the encapsulation of a probiotic lactic acid bacterium in electrospun PEO nanofibers [90]. Only $2 \%$ of the Lactobacillus plantarum cells survived the electrospinnig process. However, the cells that survived were still able to produce the antimicrobial peptide (bacteriocin) and inhibited the growth of E. faecium HKLHS that served as target strain.

5.6. Silver Nanoparticles. Silver nanoparticles were incorporated in cellulose acetate nanofibers by electrospinning cellulose acetate with $0.5 \mathrm{wt} \% \mathrm{AgNO}_{3}$ [94]. Silver particles were generated on the surface of the nanofibers after irradiation at $245 \mathrm{~nm}$. Almost all viable cells (99.9\%) of Gram-positive bacteria, E. coli, Klebsiella pneumoniae, and P. aeruginosa were killed after 18 hours of exposure to the encapsulated silver particles. Silver-loaded zirconium phosphate was spun into poly $\varepsilon$-caprolactone fibers [86]. Growth inhibition of up to $99.27 \%$ of $S$. aureus and up to $98.44 \%$ of $E$. coli was recorded when the strains were cultured in the presence of these nanofibers. Human dermal fibroblasts that attached to the nanofibers continued to proliferate, suggesting that the fibers may be used as wound dressings. Similar findings have also been reported by Rujitanaroj et al. [95]. However, some authors have reported that silver may elicit toxic side effects on human cells as discussed elsewhere in this paper. Table 1 summarizes various molecules that have been encapsulated into synthetic and natural polymers, or blends thereof, by electrospinning to facilitate their release.

\section{Natural Alternatives to Antibiotics}

Lactic acid bacteria (LAB) are a diverse group of organisms with GRAS (generally regarded as safe) status and have been consumed over decades [96]. Most species produce bacteriocins, that is, ribosomally synthesized proteins or protein complexes with bacteriostatic or bactericidal activity against closely related species $[97,98]$. The peptides have a net positive charge (cationic) and are amphiphilic or rather more hydrophobic. They intercalate into the cell membrane of sensitive cells, form pores and disrupt the proton motive force (PMF) [99-101].

Bacteriocins are classified into two major classes. Class I contains the lantibiotics that are small peptides that undergo posttranslational modifications and have lanthionine or $\beta$-methyllanthionine residues, for example, nisin, merscadin $[102,103]$. Class II contains the nonlanthioninecontaining bacteriocins that are small $(<10 \mathrm{kDa})$ heat-stable 
TABLE 1: Molecules and organisms encapsulated into electrospun nanofibers.

\begin{tabular}{|c|c|c|}
\hline Encapsulated molecules & Polymer/polymer blends & Reference \\
\hline \multicolumn{3}{|l|}{ Antibiotics } \\
\hline Rifampin & PLLA & [81] \\
\hline Doxorubicin hydrochloride & PLLA & [81] \\
\hline Paclitaxil & PLLA & {$[81]$} \\
\hline Tetracycline hydrochloride & PEVA & {$[60]$} \\
\hline Mefoxin & PLGA/PEG-b-PLLA & [82] \\
\hline \multicolumn{3}{|l|}{ Plasmid DNA } \\
\hline pCMVb encoding a $\beta$-Galactosidase & PLGA and PLA-PEG & [83] \\
\hline \multicolumn{3}{|l|}{ Growth Factors } \\
\hline Human $\beta$-nerve growth factor (NGF) & PCLEEP & {$[54]$} \\
\hline Human glialcell-derived neurotrophic factor (GDNF) & PCLEEP & {$[84]$} \\
\hline Bone morfogenetic protein-2 (BMP-2) & PLGA-Hap & [85] \\
\hline \multicolumn{3}{|l|}{ Antimicrobial compounds } \\
\hline \multirow{2}{*}{ Silver nanoparticles } & Cellulose acetate & {$[72]$} \\
\hline & PCL/silver-loaded zirconium phosphate & [86] \\
\hline \multicolumn{3}{|l|}{ Proteins } \\
\hline BSA & $\mathrm{PEO}$ & [87] \\
\hline Lysozyme & $\mathrm{PCL} / \mathrm{PEO}$ & {$[53]$} \\
\hline Lysozyme & $\mathrm{PCL} / \mathrm{PEG}$ & [77] \\
\hline Cytochrome C & PLLA/PLL & {$[61]$} \\
\hline \multicolumn{3}{|l|}{ Bacteria } \\
\hline \multicolumn{3}{|l|}{ Eschericia coli } \\
\hline Staphylococcus albus & PVA & {$[88]$} \\
\hline \multicolumn{3}{|l|}{ Micrococcus luteus } \\
\hline Eschericia coli & PEO & [89] \\
\hline Lactobacillus plantarum & $\mathrm{PEO}$ & {$[90]$} \\
\hline \multicolumn{3}{|l|}{ Bacteriophages } \\
\hline \multicolumn{3}{|l|}{ T7 } \\
\hline \multicolumn{3}{|l|}{$\mathrm{T} 4$} \\
\hline$\lambda$ & PVA & {$[88]$} \\
\hline M13 & PVP & {$[91]$} \\
\hline
\end{tabular}

TABLE 2: Classification system for bacteriocins [92].

\begin{tabular}{lc}
\hline Classes & Characteristics \\
\hline Class I & Lantibiotics \\
Class Ia & Small (19-38 amino acids), elongated, positively charged peptides that form pores \\
Class Ib & Globular peptides that interfere with essential enzymes \\
\hline Class II & Nonlanthionine containing-bacteriocins \\
Class IIa & Pediocin-like peptides that contain the YGNGVXCXXXXVXV consensus sequence in their N-terminal \\
Class IIb & Two-peptide bacteriocins, require both peptides for activity \\
Class IIc & Cyclic peptides, N- and C-terminal of peptides are covalently linked \\
Class IId & Single non-pediocin like peptides \\
\hline
\end{tabular}

peptides that do not undergo extensive post-translational modifications [92]. Examples include pediocin $\mathrm{PA}-1 / \mathrm{AcH}$, plantaricin S, enterocin AS-48, and lactococcin A [104-107]. The classes and subclasses of bacteriocins are listed in Table 2.
Some bacteriocins, such as mersacidin, have shown activity towards MRSA that have been associated with various hospital acquired infections [108]. Nisin F was also investigated as treatment for subcutaneous skin infections 
caused by S. aureus [109]. Bacteriocins are thus attractive natural alternatives to antibiotics, which can be used in the treatment of bacterial infections. A localized delivery system is, however, required to control the level and rate of bacteriocins delivered to the wound. A novel approach would be to encapsulate bacteriocins into electrospun nanofibers and use this as wound dressings for burned victims.

The feasibility of encapsulating bacteriocins into electrospun nanofibers was recently reported in [90]. The bacteriocin plantaricin 423 retained activity after electrospinning and inhibited the growth of E. faecium HKLHS and Lactobacillus sakei DSM 20017 that served as target strains. Nisin, a bacteriocin produced by Lactococcus lactis, was successfully loaded in PLLA nanoparticles by using semicontinuous compressed $\mathrm{CO}_{2}$ antisolvent precipitation [110]. Nisin was released in the active form and exerted its antibacterial activity up to 45 days, when incubated with a culture of Lactobacillus delbrueckeii.

\section{Conclusion and Future Trends}

Electrospinning is a versatile and relatively easy technique to produce large amounts of nanofibers with diverse molecules encapsulated within. The large surface to volume ratio of nanofibers allows the encapsulation of high concentrations of bacteriocins and direct delivery to sites of skin infection. The use of bacteriocins to control infections may help to prevent further increase in antibiotic resistance amongst bacteria and may prevent negative side effects some current medication has on patients. Release of bacteriocins from nanofibers can be controlled by selecting polymers of specific composition. Furthermore, specific nanofiber scaffolds can be designed that are oxygen permeable and structurally similar to the extracellular matrix (EM) in skin.

Ideally, nanofiber wound dressings should not only contain antimicrobial agents, but a combination of compounds that would accelerate the healing process and alleviate discomfort. Such compounds may include antiinflammatory and tissue repairing drugs. Although antiinflammatory drugs have been encapsulated into nanofibers, no reports have been published on the encapsulation of combined compounds.

Future research has to focus on developing nanofber wound dressings containing a combination of antimicrobial compounds, anti-inflammatory drugs, and painkillers. Furthermore, the nanofiber scaffold has to be designed to allow controlled released of the drugs over an extended period to avoid frequent changes of wound dressings. The toxicity of nanofibers needs to be researched, that is, much more in vivo studies need to be performed.

\section{References}

[1] J. Shelby and S. W. Merrell, "In vivo monitoring of postburn immune response," The Journal of Trauma, vol. 27, no. 2, pp. 213-216, 1987.

[2] U. Altoparlak, S. Erol, M. N. Akcay, F. Celebi, and A. Kadanali, "The time-related changes of antimicrobial resistance patterns and predominant bacterial profiles of burn wounds and body flora of burned patients," Burns, vol. 30, no. 7, pp. 660-664, 2004.

[3] Fire Deaths and Injuries: Fact Sheet, http://www.cdc.gov/ HomeandRecreationalSafety/Fire-Prevention/fires-factsheet .html.

[4] American Burn Associations. Burn Incidence Fact Sheet, 2002.

[5] CDC Mass Casualties fact sheet, 2006, http://www.bt.cdc .gov/masscasualties/pdf/burns-masscasualties.pdf.

[6] B. A. Pruitt Jr., A. T. McManus, S. H. Kim, and C. W. Goodwin, "Burn wound infections: current status," World Journal of Surgery, vol. 22, no. 2, pp. 135-145, 1998.

[7] S. Erol, U. Altoparlak, M. N. Akcay, F. Celebi, and M. Parlak, "Changes of microbial flora and wound colonization in burned patients," Burns, vol. 30, no. 4, pp. 357-361, 2004.

[8] H. Vindenes and R. Bjerknes, "Microbial colonization of large wounds," Burns, vol. 21, no. 8, pp. 575-579, 1995.

[9] H. M. Bruck, G. Nash, J. M. Stein, and R. B. Lindberg, "Studies on the occurrence and significance of yeasts and fungi in the burn wound," Annals of Surgery, vol. 176, no. 1, pp. 108-110, 1972.

[10] J. W. Costerton, P. S. Stewart, and E. P. Greenberg, "Bacterial biofilms: a common cause of persistent infections," Science, vol. 284, no. 5418, pp. 1318-1322, 1999.

[11] R. Edwards and K. G. Harding, "Bacteria and wound healing," Current Opinion in Infectious Diseases, vol. 17, no. 2, pp. 91-96, 2004.

[12] H. Ceri, M. E. Olson, C. Stremick, R. R. Read, D. Morck, and A. Buret, "The Calgary biofilm device: new technology for rapid determination of antibiotic susceptibilities of bacterial biofilms," Journal of Clinical Microbiology, vol. 37, no. 6, pp. 1771-1776, 1999.

[13] D. de Beer, P. Stoodley, and Z. Lewandowski, "Liquid flow in heterogeneous biofilms," Biotechnology and Bioengineering, vol. 44, no. 5, pp. 636-641, 1994.

[14] D. Church, S. Elsayed, O. Reid, B. Winston, and R. Lindsay, "Burn wound infections," Clinical Microbiology Reviews, vol. 19, no. 2, pp. 403-434, 2006.

[15] S. G. Santucci, S. Gobara, C. R. Santos, C. Fontana, and A. S. Levin, "Infections in a burn intensive care unit: experience of seven years," Journal of Hospital Infection, vol. 53, no. 1, pp. 6-13, 2003.

[16] M. Guggenheim, R. Zbinden, A. E. Handschin, A. Gohritz, M. A. Altintas, and P. Giovanoli, "Changes in bacterial isolates from burn wounds and their antibiograms: a 20-year study (1986-2005)," Burns, vol. 35, no. 4, pp. 553-560, 2009.

[17] G. D. Taylor, P. Kibsey, T. Kirkland, E. Burroughs, and E. Tredget, "Predominance of staphylococcal organisms in infections occurring in a burns intensive care unit," Burns, vol. 18, no. 4, pp. 332-335, 1992.

[18] M. I. Lesseva and O. G. Hadjiiski, "Staphylococcal infections in the Sofia Burn Centre, Bulgaria," Burns, vol. 22, no. 4, pp. 279-282, 1996.

[19] H. Chim, B. H. Tan, and C. Song, "Five-year review of infections in a burn intensive care unit: high incidence of Acinetobacter baumannii in a tropical climate," Burns, vol. 33, no. 8, pp. 1008-1014, 2007.

[20] J. Y. Kim, "Understanding the evolution of methicillinresistant Staphylococcus aureus," Clinical Microbiology Newsletter, vol. 31, no. 3, pp. 17-23, 2009.

[21] C. J. Hackbarth and H. F. Chambers, "Methicillin-resistant staphylococci: genetics and mechanisms of resistance," Antimicrobial Agents and Chemotherapy, vol. 33, no. 7, pp. 991-994, 1989. 
[22] A. P. Fraise, K. Mitchell, S. J. O'Brien, K. Oldfield, and R. Wise, "Methicillin-resistant Staphylococcus aureus (MRSA) in nursing homes in a major UK city: an anonymized point prevalence survey," Epidemiology and Infection, vol. 118, no. 1, pp. 1-5, 1997.

[23] K. Hiramatsu, "Molecular evolution of MRSA," Microbiology and Immunology, vol. 39, no. 8, pp. 531-543, 1995.

[24] N. Cook, "Methicillin-resistant Staphylococcus aureus versus the burn patient," Burns, vol. 24, no. 2, pp. 91-98, 1998.

[25] B. Slocombe and C. Perry, "The antimicrobial activity of mupirocinan update on resistance," Journal of Hospital Infection, vol. 19, supplement 2, pp. 19-25, 1991.

[26] E. E. Udo, J. W. Pearman, and W. B. Grubb, "Emergence of high-level mupirocin resistance in methicillin-resistant Staphylococcus aureus in Western Australia," Journal of Hospital Infection, vol. 26, no. 3, pp. 157-165, 1994.

[27] E. C. Smoot, J. O. Kucan, D. R. Graham, and J. E. Barenfanger, "Susceptibility testing of topical antimicrobials against methicillin-resistant Staphylococcus aureus," Journal of Burn Care \& Research, vol. 13, no. 2, pp. 198-202, 1992.

[28] O. Scheel, D. J. Lyon, V. T. Rosdahl, F. A. B. Adeyemi-Dora, T. K. W. Ling, and A. F. B. Cheng, "In-vitro susceptibility of isolates of methicillin-resistant Staphylococcus aureus 19881993," Journal of Antimicrobial Chemotherapy, vol. 37, no. 2, pp. 243-251, 1996.

[29] K. Hiramatsu, H. Hanaki, T. Ino, K. Yabuta, T. Oguri, and F. C. Tenover, "Methicillin-resistant Staphylococcus aureus clinical strain with reduced vancomycin susceptibility," Journal of Antimicrobial Chemotherapy, vol. 40, no. 1, pp. 135-136, 1997.

[30] H. C. Neu, “The crisis in antibiotic resistance," Science, vol. 257, no. 5073, pp. 1064-1073, 1992.

[31] P. V. AshaRani, G. L. K. Mun, M. P. Hande, and S. Valiyaveettil, "Cytotoxicity and genotoxicity of silver nanoparticles in human cells," ACS Nano, vol. 3, no. 2, pp. 279-290, 2009.

[32] H. Matsumura, N. Yoshizawa, A. Narumi, N. Harunari, A. Sugamata, and K. Watanabe, "Effective control of methicillin-resistant Staphylococcus aureus in a burn unit," Burns, vol. 22, no. 4, pp. 283-286, 1996.

[33] B. A. Pruitt Jr., J. A. O’Neill Jr., J. A. Moncrief, and R. B. Lindberg, "Successful control of burn-wound sepsis," The Journal of the American Medical Association, vol. 203, no. 12, pp. 1054-1056, 1968.

[34] V. K. M. Poon and A. Burd, "In vitro cytotoxity of silver: implication for clinical wound care," Burns, vol. 30, no. 2, pp. 140-147, 2004.

[35] A. B. Lansdown, "Silver. 2: toxicity in mammals and how its products aid wound repair," Journal of Wound Care, vol. 11, no. 5, pp. 173-177, 2002.

[36] K. Bridges, A. Kidson, E. J. L. Lowbury, and M. D. Wilkins, "Gentamicin- and silver-resistant Pseudomonas in a burns unit," British Medical Journal, vol. 1, no. 6161, pp. 446-449, 1979.

[37] X.-Z. Li, H. Nikaido, and K. E. Williams, "Silver-resistant mutants of Escherichia coli display active efflux of $\mathrm{Ag}+$ and are deficient in porins," Journal of Bacteriology, vol. 179, no. 19, pp. 6127-6132, 1997.

[38] S. Silver, L. T. Phung, and G. Silver, "Silver as biocides in burn and wound dressings and bacterial resistance to silver compounds," Journal of Industrial Microbiology and Biotechnology, vol. 33, no. 7, pp. 627-634, 2006.

[39] S. P. Pegg, "Multiple resistant Staphylococcus aures," Annals of the Academy of Medicine Singapore, vol. 21, no. 5, pp. 664666, 1992.
[40] M. M. Stefanides Sr., C. E. Copeland, S. D. Kominos, and R. B. Yee, "In vitro penetration of topical antiseptics through eschar of burn patients," Annals of Surgery, vol. 183, no. 4, pp. 358-364, 1976.

[41] H. Rode, D. Hanslo, P. M. de Wet, A. J. W. Millar, and S. Cywes, "Efficacy of mupirocin in methicillin-resistant Staphylococcus aureus burn wound infection," Antimicrobial Agents and Chemotherapy, vol. 33, no. 8, pp. 1358-1361, 1989.

[42] X. Xu, X. Zhuang, X. Chen, X. Wang, L. Yang, and X. Jing, "Preparation of core-sheath composite nanofibers by emulsion electrospinning," Macromolecular Rapid Communications, vol. 27, no. 19, pp. 1637-1642, 2006.

[43] K. Dunn and V. Edwards-Jones, "The role of Acticoat ${ }^{\mathrm{TM}}$ with nanocrystalline silver in the management of burns," Burns, vol. 30, supplement 1, pp. S1-S9, 2004.

[44] J. Heggers, R. E. Goodheart, J. Washington et al., “Therapeutic efficacy of three silver dressings in an infected animal model," Journal of Burn Care and Rehabilitation, vol. 26, no. 1, pp. 53-56, 2005.

[45] K. Greenhalgh and E. Turos, "In vivo studies of polyacrylate nanoparticle emulsions for topical and systemic applications," Nanomedicine, vol. 5, no. 1, pp. 46-54, 2009.

[46] Y.-H. Hsin, C.-F. Chen, S. Huang, T.-S. Shih, P.-S. Lai, and P. J. Chueh, "The apoptotic effect of nanosilver is mediated by a ROS- and JNK-dependent mechanism involving the mitochondrial pathway in NIH3T3 cells," Toxicology Letters, vol. 179, no. 3, pp. 130-139, 2008.

[47] J. H. Sung, J. H. Ji, J. U. Yoon et al., "Lung function changes in Sprague-Dawley rats after prolonged inhalation exposure to silver nanoparticles," Inhalation Toxicology, vol. 20, no. 6, pp. 567-574, 2008.

[48] H.-J. Yen, S.-H. Hsu, and C.-L. Tsai, "Cytotoxicity and immunological response of gold and silver nanoparticles of different sizes," Small, vol. 5, no. 13, pp. 1553-1561, 2009.

[49] Z.-M. Huang, Y.-Z. Zhang, M. Kotaki, and S. Ramakrishna, "A review on polymer nanofibers by electrospinning and their applications in nanocomposites," Composites Science and Technology, vol. 63, no. 15, pp. 2223-2253, 2003.

[50] K. Yoon, K. Kim, X. Wang, D. Fang, B. S. Hsiao, and B. Chu, "High flux ultrafiltration membranes based on electrospun nanofibrous PAN scaffolds and chitosan coating," Polymer, vol. 47, no. 7, pp. 2434-2441, 2006.

[51] J. Theron, J. A. Walker, and T. E. Cloete, "Nanotechnology and water treatment: applications and emerging opportunities," Critical Reviews in Microbiology, vol. 34, no. 1, pp. 4369, 2008.

[52] S. Agarwal, J. H. Wendorff, and A. Greiner, "Use of electrospinning technique for biomedical applications," Polymer, vol. 49, no. 26, pp. 5603-5621, 2008.

[53] T. G. Kim, D. S. Lee, and T. G. Park, "Controlled protein release from electrospun biodegradable fiber mesh composed of poly( $\varepsilon$-caprolactone) and poly(ethylene oxide)," International Journal of Pharmaceutics, vol. 338, no. 1-2, pp. 276283, 2007.

[54] S. Y. Chew, J. Wen, E. K. F. Yim, and K. W. Leong, "Sustained release of proteins from electrospun biodegradable fibers," Biomacromolecules, vol. 6, no. 4, pp. 2017-2024, 2005.

[55] F. Quaglia, "Bioinspired tissue engineering: the great promise of protein delivery technologies," International Journal of Pharmaceutics, vol. 364, no. 2, pp. 281-297, 2008. 
[56] H. Jiang, Y. Hu, Y. Li, P. Zhao, K. Zhu, and W. Chen, "A facile technique to prepare biodegradable coaxial electrospun nanofibers for controlled release of bioactive agents," Journal of Controlled Release, vol. 108, no. 2-3, pp. 237-243, 2005.

[57] J. R. Porter, A. Henson, and K. C. Popat, "Biodegradable poly ( $\varepsilon$-caprolactone) nanowires for bone tissue engineering applications," Biomaterials, vol. 30, no. 5, pp. 780-788, 2009.

[58] A. Aluigi, A. Varesano, A. Montarsolo et al., "Electrospinning of keratin/poly(ethylene oxide) blend nanofibers," Journal of Applied Polymer Science, vol. 104, no. 2, pp. 863-870, 2007.

[59] H. Tabesh, G. H. Amoabediny, N. S. Nik et al., "The role of biodegradable engineered scaffolds seeded with Schwann cells for spinal cord regeneration," Neurochemistry International, vol. 54, no. 2, pp. 73-83, 2009.

[60] E.-R. Kenawy, G. L. Bowlin, K. Mansfield et al., "Release of tetracycline hydrochloride from electrospun poly(ethyleneco-vinylacetate), poly(lactic acid), and a blend," Journal of Controlled Release, vol. 81, no. 1-2, pp. 57-64, 2002.

[61] S. Maretschek, A. Greiner, and T. Kissel, "Electrospun biodegradable nanofiber nonwovens for controlled release of proteins," Journal of Controlled Release, vol. 127, no. 2, pp. 180-187, 2008.

[62] Y. Nagai, L. D. Unsworth, S. Koutsopoulos, and S. Zhang, "Slow release of molecules in self-assembling peptide nanofiber scaffold," Journal of Controlled Release, vol. 115, no. 1, pp. 18-25, 2006.

[63] J. D. Hartgerink, E. Beniash, and S. I. Stupp, "Self-assembly and mineralization of peptide-amphiphile nanofibers," Science, vol. 294, no. 5547, pp. 1684-1688, 2001.

[64] M. J. Pender and L. G. Sneddon, "An efficient template synthesis of aligned boron carbide nanofibers using a singlesource molecular precursor," Chemistry of Materials, vol. 12, no. 2, pp. 280-283, 2000.

[65] E. P. S. Tan and C. T. Lim, "Physical properties of a single polymeric nanofiber," Applied Physics Letters, vol. 84, no. 9, pp. 1603-1605, 2004.

[66] A. Huczko, "Template-based synthesis of nanomaterials," Applied Physics A, vol. 70, no. 4, pp. 365-376, 2000.

[67] E. D. Boland, G. E. Wnek, D. G. Simpson, K. J. Pawlowski, and G. L. Bowlin, "Tailoring tissue engineering scaffolds using electrostatic processing techniques: a study of poly(glycolic acid) electrospinning," Journal of Macromolecular Science, Part A, vol. 38, no. 12, pp. 1231-1243, 2001.

[68] A. Theron, E. Zussman, and A. L. Yarin, "Electrostatic fieldassisted alignment of electrospun nanofibres," Nanotechnology, vol. 12, no. 3, pp. 384-390, 2001.

[69] H. Fong and D. H. Reneker, "Electrospinning and formation of nano-fibers," in Structure Formation in Polymeric Fibers, D. R. Salem, Ed., pp. 225-246, Hanser, Munich, Germany, 2001.

[70] Y. Wu, L. A. Carnell, and R. L. Clark, "Control of electrospun mat width through the use of parallel auxiliary electrodes," Polymer, vol. 48, no. 19, pp. 5653-5661, 2007.

[71] H. Fong, W. Liu, C.-S. Wang, and R. A. Vaia, "Generation of electrospun fibers of nylon 6 and nylon 6-montmorillonite nanocomposite," Polymer, vol. 43, no. 3, pp. 775-780, 2002.

[72] Z. Sun, E. Zussman, A. L. Yarin, J. H. Wendorff, and A. Greiner, "Compound core-shell polymer nanofibers by coelectrospinning," Advanced Materials, vol. 15, no. 22, pp. 1929-1932, 2003.

[73] D. Liang, B. S. Hsiao, and B. Chu, "Functional electrospun nanofibrous scaffolds for biomedical applications," Advanced Drug Delivery Reviews, vol. 59, no. 14, pp. 1392-1412, 2007.
[74] J. M. Deitzel, J. Kleinmeyer, D. Harris, and N. C. Beck Tan, "The effect of processing variables on the morphology of electrospun nanofibers and textiles," Polymer, vol. 42, no. 1, pp. 261-272, 2001.

[75] Q. Yang, L. I. Zhenyu, Y. Hong et al., "Influence of solvents on the formation of ultrathin uniform poly(vinyl pyrrolidone) nanofibers with electrospinning," Journal of Polymer Science, vol. 42, no. 20, pp. 3721-3726, 2004.

[76] H. Fong, I. Chun, and D. H. Reneker, "Beaded nanofibers formed during electrospinning," Polymer, vol. 40, no. 16, pp. 4585-4592, 1999.

[77] Y. Li, H. Jiang, and K. Zhu, "Encapsulation and controlled release of lysozyme from electrospun poly $(\varepsilon-$ caprolactone)/poly(ethylene glycol) non-woven membranes by formation of lysozyme-oleate complexes," Journal of Materials Science, vol. 19, no. 2, pp. 827-832, 2008.

[78] Y. Zhou, D. Yang, X. Chen, Q. Xu, F. Lu, and J. Nie, "Electrospun water-soluble carboxyethyl chitosan/poly(vinyl alcohol) nanofibrous membrane as potential wound dressing for skin regeneration," Biomacromolecules, vol. 9, no. 1, pp. 349-354, 2008.

[79] B.-M. Min, S. W. Lee, J. N. Lim et al., "Chitin and chitosan nanofibers: electrospinning of chitin and deacetylation of chitin nanofibers," Polymer, vol. 45, no. 21, pp. 7137-7142, 2004.

[80] T. Dai, G. P. Tegos, M. Burkatovskaya, A. P. Castano, and M. R. Hamblin, "Chitosan acetate bandage as a topical antimicrobial dressing for infected burns," Antimicrobial Agents and Chemotherapy, vol. 53, no. 2, pp. 393-400, 2009.

[81] J. Zeng, X. Xu, X. Chen et al., "Biodegradable electrospun fibers for drug delivery," Journal of Controlled Release, vol. 92, no. 3, pp. 227-231, 2003.

[82] K. Kim, Y. K. Luu, C. Chang et al., "Incorporation and controlled release of a hydrophilic antibiotic using poly(lactideco-glycolide)-based electrospun nanofibrous scaffolds," Journal of Controlled Release, vol. 98, no. 1, pp. 47-56, 2004.

[83] Y. K. Luu, K. Kim, B. S. Hsiao, B. Chu, and M. Hadjiargyrou, "Development of a nanostructured DNA delivery scaffold via electrospinning of PLGA and PLA-PEG block copolymers," Journal of Controlled Release, vol. 89, no. 2, pp. 341-353, 2003.

[84] S. Y. Chew, R. Mi, A. Hoke, and K. W. Leong, "Aligned protein-polymer composite fibers enhance nerve regeneration: a potential tissue-engineering platform," Advanced Functional Materials, vol. 17, no. 8, pp. 1288-1296, 2007.

[85] Y.-C. Fu, H. Nie, M.-L. Ho, C.-K. Wang, and C.-H. Wang, "Optimized bone regeneration based on sustained release from three-dimensional fibrous PLGA/HAp composite scaffolds loaded with BMP-2," Biotechnology and Bioengineering, vol. 99, no. 4, pp. 996-1006, 2008.

[86] Y.-Y. Duan, J. Jia, S.-H. Wang, W. Yan, L. Jin, and Z.-Y. Wang, "Preparation of antimicrobial poly(e-caprolactone) electrospun nanofibers containing silver-loaded zirconium phosphate nanoparticles," Journal of Applied Polymer Science, vol. 106, no. 2, pp. 1208-1214, 2007.

[87] T. Kowalczyk, A. Nowicka, D. Elbaum, and T. A. Kowalewski, "Electrospinning of bovine serum albumin optimization and the use for production of biosensors," Biomacromolecules, vol. 9, no. 7, pp. 2087-2090, 2008.

[88] W. Salalha, J. Kuhn, Y. Dror, and E. Zussman, "Encapsulation of bacteria and viruses in electrospun nanofibres," Nanotechnology, vol. 17, no. 18, article 25, pp. 4675-4681, 2006.

[89] M. Gensheimer, M. Becker, A. Brandis-Heep, J. H. Wendorff, R. K. Thauer, and A. Greiner, "Novel biohybrid materials by electrospinning: nanofibers of poly (ethylene oxide) and 
living bacteria," Advanced Materials, vol. 19, no. 18, pp. 2480 2482, 2007.

[90] T. D. J. Heunis, M. Botes, and L. M.T. Dicks, "Encapsulation of Lactobacillus plantarum 423 and its bacteriocin in nanofibers," Probiotics and Antimicrobial Proteins, vol. 2, no. 1, pp. 46-51, 2010.

[91] S.-W. Lee and A. M. Belcher, "Virus-based fabrication of micro- and nanofibers using electrospinning," Nano Letters, vol. 4, no. 3, pp. 387-390, 2004.

[92] P. D. Cotter, C. Hill, and R. P. Ross, "Bacteriocins: developing innate immunity for food," Nature Reviews Microbiology, vol. 3, no. 10, pp. 777-788, 2005.

[93] Y. Wang, Q. Yang, G. Shan et al., "Preparation of silver nanoparticles dispersed in polyacrylonitrile nanofiber film spun by electrospinning," Materials Letters, vol. 59, no. 2425, pp. 3046-3049, 2005.

[94] W. K. Son, J. H. Youk, and W. H. Park, "Antimicrobial cellulose acetate nanofibers containing silver nanoparticles," Carbohydrate Polymers, vol. 65, no. 4, pp. 430-434, 2006.

[95] P.-O. Rujitanaroj, N. Pimpha, and P. Supaphol, "Wounddressing materials with antibacterial activity from electrospun gelatin fiber mats containing silver nanoparticles," Polymer, vol. 49, no. 21, pp. 4723-4732, 2008.

[96] L. De Vuyst and E.J. Vandamme, "Nisin, a lantibiotic produced by Lactococcus lactis subsp. lactis: properties, biosynthesis, fermentation and application," in Bacteriocins of Lactic acid Bacteria, L. De Vuyst and E. J. Vandamme, Eds., pp. 151-221, Chapman \& Hall, Boca Raton, Fla, USA, 1994.

[97] R. W. Jack, J. R. Tagg, and B. Ray, "Bacteriocins of grampositive bacteria," Microbiological Reviews, vol. 59, no. 2, pp. 171-200, 1995.

[98] T. R. Klaenhammer, "Genetics of bacteriocins produced by lactic acid bacteria," FEMS Microbiology Reviews, vol. 12, no. 1-3, pp. 39-85, 1993.

[99] G. N. Moll, W. N. Konings, and A. J. M. Driessen, "Bacteriocins: mechanism of membrane insertion and pore formation," Antonie van Leeuwenhoek, vol. 76, no. 1-4, pp. 185-198, 1999.

[100] T. Abee, L. Krockel, and C. Hill, "Bacteriocins: modes of action and potentials in food preservation and control of food poisoning," International Journal of Food Microbiology, vol. 28, no. 2, pp. 169-185, 1995.

[101] O. McAuliffe, R. P. Ross, and C. Hill, "Lantibiotics: structure, biosynthesis and mode of action," FEMS Microbiology Reviews, vol. 25, no. 3, pp. 285-308, 2001.

[102] H.-G. Sahl and G. Bierbaum, "Lantibiotics: biosynthesis and biological activities of uniquely modified peptides from gram-positive bacteria," Annual Review of Microbiology, vol. 52, pp. 41-79, 1998.

[103] K. Altena, A. Guder, C. Cramer, and G. Bierbaum, "Biosynthesis of the lantibiotic mersacidin: organization of a type B lantibiotic gene cluster," Applied and Environmental Microbiology, vol. 66, no. 6, pp. 2565-2571, 2000.

[104] M. L. Chikindas, M. J. Garcia-Garcera, A. J. M. Driessen et al., "Pediocin PA-1, a bacteriocin from Pediococcus acidilactici PAC1.0, forms hydrophilic pores in the cytoplasmic membrane of target cells," Applied and Environmental Microbiology, vol. 59, no. 11, pp. 3577-3584, 1993.

[105] R. Jiménez-Díaz, R. M. Rios-Sénchez, M. Desmazeaud, J. L. Ruiz-Barba, and J. C. Piard -, "Plantaricins S and T, two new bacteriocins produced by Lactobacillus plantarum LPCO10 isolated from a green olive fermentation," Applied and Environmental Microbiology, vol. 59, no. 5, pp. 14161424, 1993.
[106] A. Galvez, G. Gimenez-Gallego, M. Maqueda, and E. Valdivia, "Purification and Amino 574 Acid Composition of Peptide AntibioticAS-48 Produced by Streptococcus (Enterococcus) faecalis subsp. liquefaciens S-48," Antimicrobial Agents and Chemotherapy, vol. 33, no. 4, pp. 437-441, 1989.

[107] H. Holo, O. Nilssen, and I. F. Nes, "Lactococcin A, a new bacteriocin from Lactococcus lactis subsp. cremoris: isolation and characterization of the protein and its gene," Journal of Bacteriology, vol. 173, no. 12, pp. 3879-3887, 1991.

[108] D. Kruszewska, H.-G. Sahl, G. Bierbaum, U. Pag, S. O. Hynes, and Å. Ljungh, "Mersacidin eradicates methicillin-resistant Staphylococcus aureus (MRSA) in a mouse rhinitis model," Journal of Antimicrobial Chemotherapy, vol. 54, no. 3, pp. 648-653, 2004.

[109] M. De Kwaadsteniet, C. A. Van Reenen, and L. M.T. Dicks, "Evaluation of nisin $\mathrm{F}$ in the treatment of subcutaneous skin infections, as monitored by using a bioluminescent strain of Staphylococcus aureus," Probiotics and Antimicrobial Proteins, vol. 2, no. 2, pp. 61-65, 2010.

[110] S. Salmaso, N. Elvassore, A. Bertucco, A. Lante, and P. Caliceti, "Nisin-loaded poly-L-lactide nano-particles produced by $\mathrm{CO} 2$ anti-solvent precipitation for sustained antimicrobial activity," International Journal of Pharmaceutics, vol. 287, no. 1-2, pp. 163-173, 2004. 


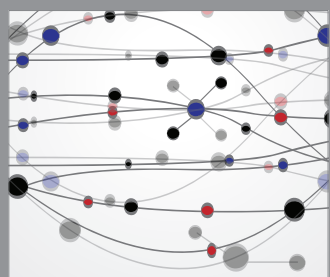

The Scientific World Journal
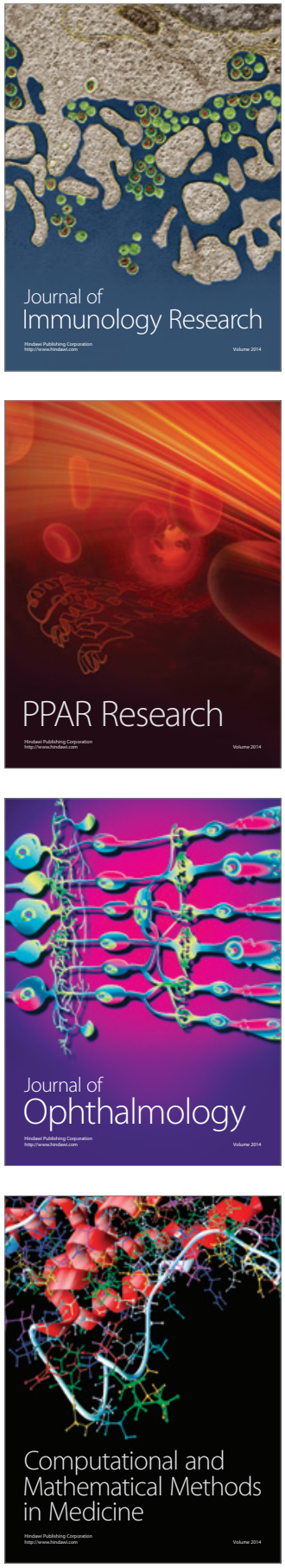

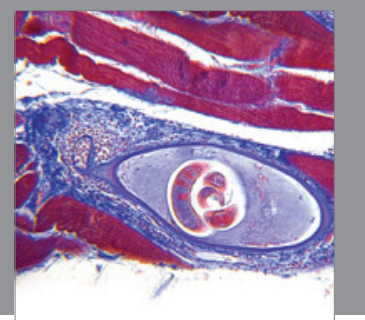

Gastroenterology

Research and Practice
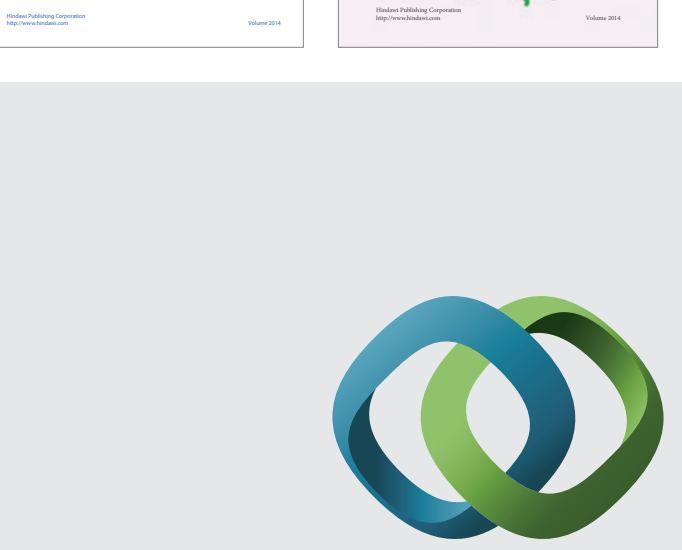

\section{Hindawi}

Submit your manuscripts at

http://www.hindawi.com
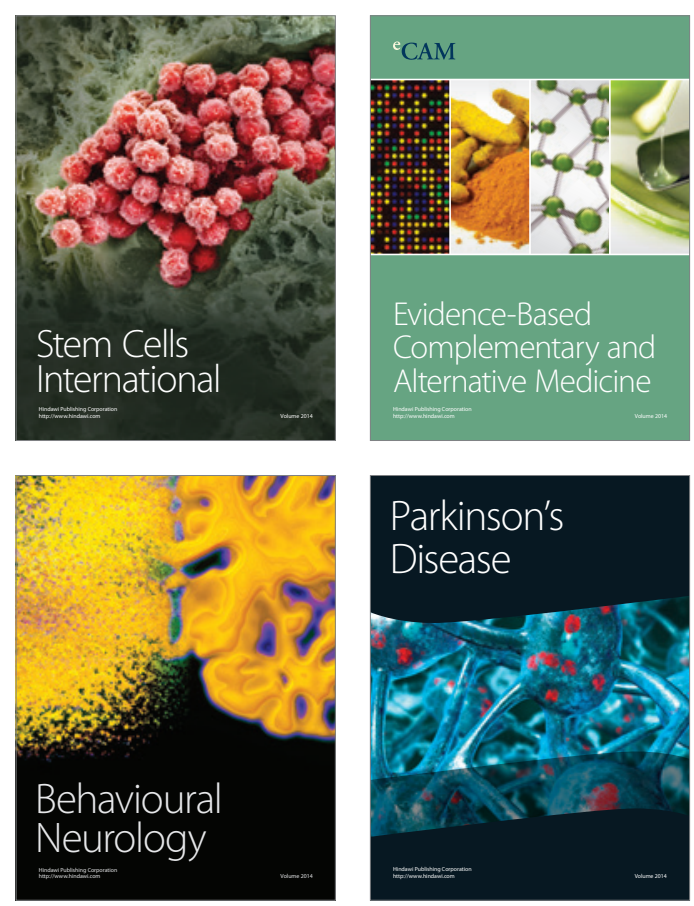

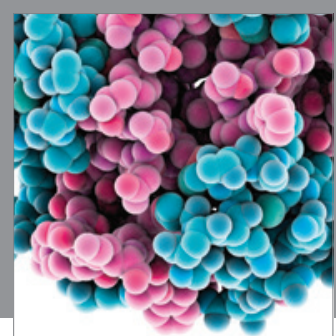

Journal of
Diabetes Research

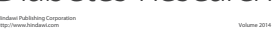

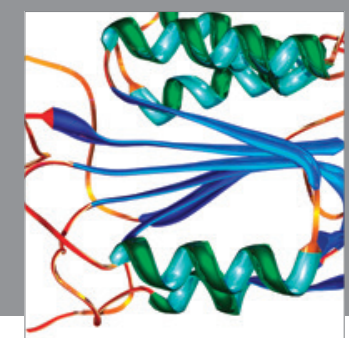

Disease Markers
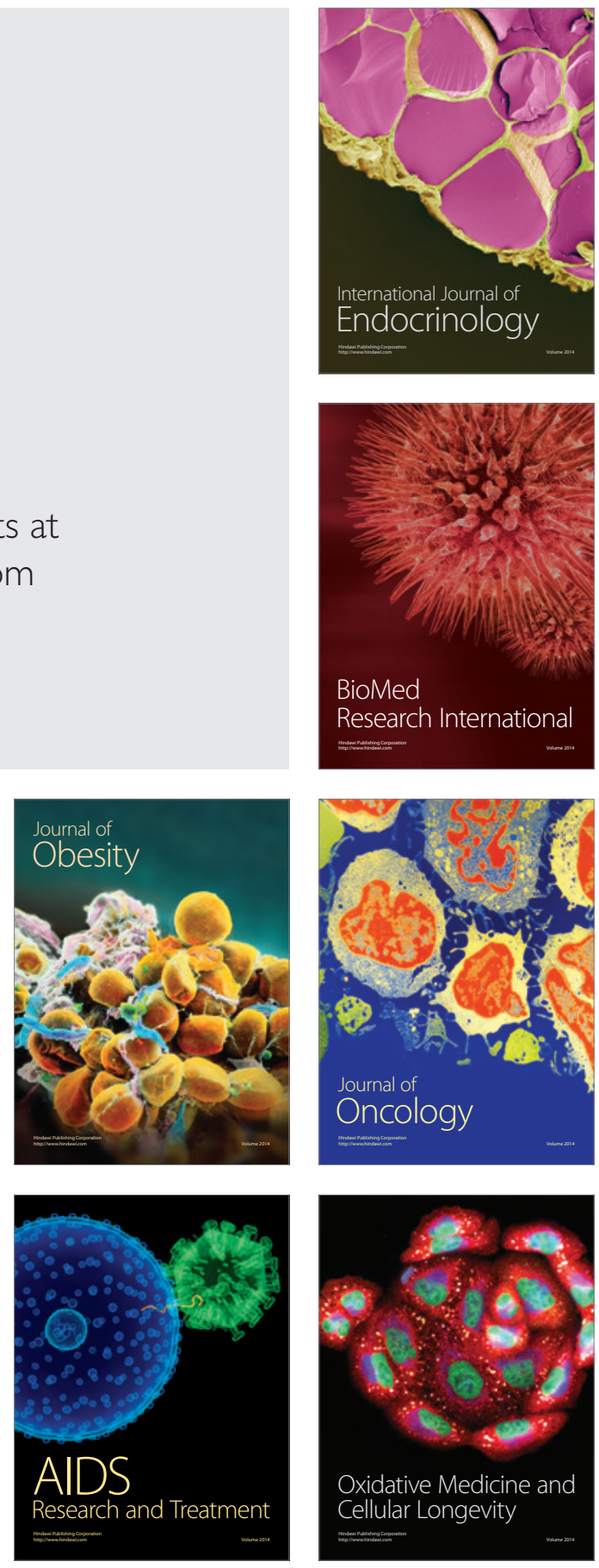